\title{
Effects of irradiance and spectral composition on the establishment of macroalgae in streams in southern Brazil
}

\author{
Aurélio Fajar Tonetto ${ }^{1}$, Ciro Cesar Zanini Branco ${ }^{1 *}$ and Cleto Kaveski Peres ${ }^{2}$ \\ ${ }^{1}$ Laboratory of Aquatic Biology, Department of Biological Sciences, São Paulo State University, UNESP, Av. Dom Antônio, 2100, \\ 19806-900, Assis, SP, Brazil \\ ${ }^{2}$ Federal University of Latin American Integration, UNILA, Av. Tancredo Neves, 6731, Itaipu Technological Park 85867-970, \\ Foz do Iguaçu, PR, Brazil
}

Received 22 June 2012; Accepted 26 August 2012

\begin{abstract}
The relative effects of irradiance and spectral composition on the colonization and development of macroalgal communities were examined in four streams exposed to full sunlight in southern Brazil. A set of solar filters surrounded the artificial substrata to provide various quantitative and qualitative light conditions. In addition to the control, the conditions were full sunlight attenuated by 50,70 and $90 \%$, blue light (filter transmitting 430-500 nm), green light (500-600 nm) and red light (>600 nm). Macroalgal percent cover was determined three times during the colonization period (15, 39 and 70 days). Significant differences occurred in the mean values for macroalgal community percent cover between treatments at 15 and 39 days, suggesting that early and intermediate stages of the colonization were directly influenced by irradiance. There was an almost complete absence of macroalgae with $90 \%$ attentuation, but progressive increases with 70 and $50 \%$ attenuation. However, the mean values for macroalgal community percent cover did not differ significantly between color treatments, suggesting that the effects of irradiance on macroalgal colonization were stronger than those of spectral composition at similar intensity. The quantitative responses differed among the taxa.
\end{abstract}

Key words: Irradiance / light availability / lotic system / spectral composition / stream macroalgae

\section{Introduction}

Light is an important factor in the determination of structure and function of the algal communities in lotic ecosystems (Shortreed and Stockner, 1983; King and Cummins, 1989). Spatio-temporal variation in the characteristics of the riparian vegetation and the water column are the main environmental factors that determine the availability of light energy for macroalgal communities in these ecosystems (DeNicola and Hoagland, 1992; Hill et al., 2001).

In general, the photosynthetic rate is likely to be lower in shaded than non-shaded areas (Hill et al., 1995; Roberts et al., 2004; Rier et al., 2006). However, algal taxa differ in ability to acclimatize to different levels of irradiance (Necchi, 2004), which aids their success in specific environments (Branco and Necchi, 1996).

Information on the effects of specific wavelengths on benthic algae of rivers and streams is relatively scarce (Antoine and Benson-Evans, 1983a, 1983b; Hill, 1996),

\footnotetext{
*Corresponding author: czbranco@assis.unesp.br
}

especially for macroscopic species. Research on the influence of light conditions on lotic macroalgae has mostly concerned physiological aspects (Falkowski and LaRoche, 1991; Necchi, 2004) that help understanding of cellular processes, but contributed less to ecological understanding. Nevertheless, there is some evidence for a strong relationship between irradiance and spectral composition with the ecological response of these communities. In a study of the composition and seasonal dynamics of lotic macroalgal communities on Rhode Island, USA, Sheath and Burkholder (1985) suggested that the presence of riparian vegetation, which leads to marked absorption of blue and red regions of the spectrum, may be an important factor responsible for the absence of green algae in streams where this vegetation is abundant. Similarly, Branco and Necchi (1996), in a study of the floristic composition of the stream macroalgal communities in a large area of Atlantic Forest from southeastern Brazil, attributed the quantity and quality of the available light to be the main factor explaining the higher representation of Rhodophyta than Chlorophyta in streams with extensive vegetation coverage. 
The aim of the present study was to experimentally evaluate the relative effects of irradiance values and spectral composition on macroalgal colonization in subtropical streams. This was done by measuring the influence of different light conditions on changes in percentage cover during a colonization period of 70 days. The hypothesis was that under conditions of low irradiance, communities would show lower abundance, while, under different spectral compositions, colonization would be mediated by a selective mechanism in which representatives of different taxonomic divisions would respond according to their pigment complex.

\section{Material and methods}

The study was conducted in four streams in the Pedras River watershed $\left(25^{\circ} 13^{\prime} 10^{\prime \prime} \mathrm{S}-25^{\circ} 26^{\prime} 24^{\prime \prime} \mathrm{S} ; \quad 51^{\circ} 13^{\prime} 10^{\prime \prime} \mathrm{W}-\right.$ $51^{\circ} 28^{\prime} 40^{\prime \prime} \mathrm{W}$ ) in the state of Paraná, southern Brazil. In all the stream segments where experiments were conducted the light intensity reaching the water column was $100 \%$ of the available light, turbidity was low, depth was enough to permit sampler submersion during the entire experimental period and the substratum is predominantly boulders and cobbles $(\sim 90 \%)$.

During a previous study, we had noted that macroalgae belonging to Chlorophyta, Cyanobacteria and Rhodophyta were all present on natural rocky substrates in these streams. The macroalgae concept used in this study follows the definition by Sheath and Cole (1992).

The sampler used for the experiment consisted of square acrylic tubes $(15 \mathrm{~cm} \times 8 \mathrm{~cm} \times 8 \mathrm{~cm})$. Inside each sampler, we installed a removable sterile plaque made of rugged glass with the same width and length as the acrylic tubes (total area $=120 \mathrm{~cm}^{2}$ ). This plaque, which had never been exposed to colonization, provided the artificial substrate used to evaluate the response of the communities to light treatment. The selection of the material and texture of the artificial substrate was made according to Branco et al. (2010).

Variation in irradiance and spectral composition was obtained by applying reducing films (Insulfilm ${ }^{\mathrm{TM}}$ ) of the automotive type over the external walls of the acrylic tubes. These films have an effect similar to that produced by a natural vegetation cover (Simão et al., 2008). The following treatments were used: (i) control - samplers without film (CT $-904.2 \pm 59.6 \mu \mathrm{mol} . \mathrm{m}^{-2} \cdot \mathrm{s}^{-1}$ ); (ii) quantitative treatment - films with $50 \%$ (IR50 $471.0 \pm 44 \mu$ mol.m ${ }^{-2} . s^{-1}$ ), $70 \%$ (IR70 - 300.3 \pm 37.6 $\mu \mathrm{mol} . \mathrm{m}^{-2} \cdot \mathrm{s}^{-1}$ ) and $90 \%$ (IR90 - 89.2 $\pm 14.9 \mu \mathrm{mol}$. $\mathrm{m}^{-2} \cdot \mathrm{s}^{-1}$ ) light attenuation; (iii) qualitative treatment films of blue (BL $-533.1 \pm 69.3 \mu \mathrm{mol} . \mathrm{m}^{-2} . \mathrm{s}^{-1}$ ), green $\left(\mathrm{GR}-489.1 \pm 34.4 \mu \mathrm{mol} . \mathrm{m}^{-2} . \mathrm{s}^{-1}\right)$ and red light (RD $417.4 \pm 43.3 \mu \mathrm{mol} . \mathrm{m}^{-2} \cdot \mathrm{s}^{-1}$ ). In both quantitative and qualitative treatments, a reduction in unfiltered light was observed (Fig. 1). Particularly in quantitative treatments, the red part of the spectrum was more intensely reduced than other wavelengths (Fig. 1). The irradiance values among the qualitative treatments were not statistically
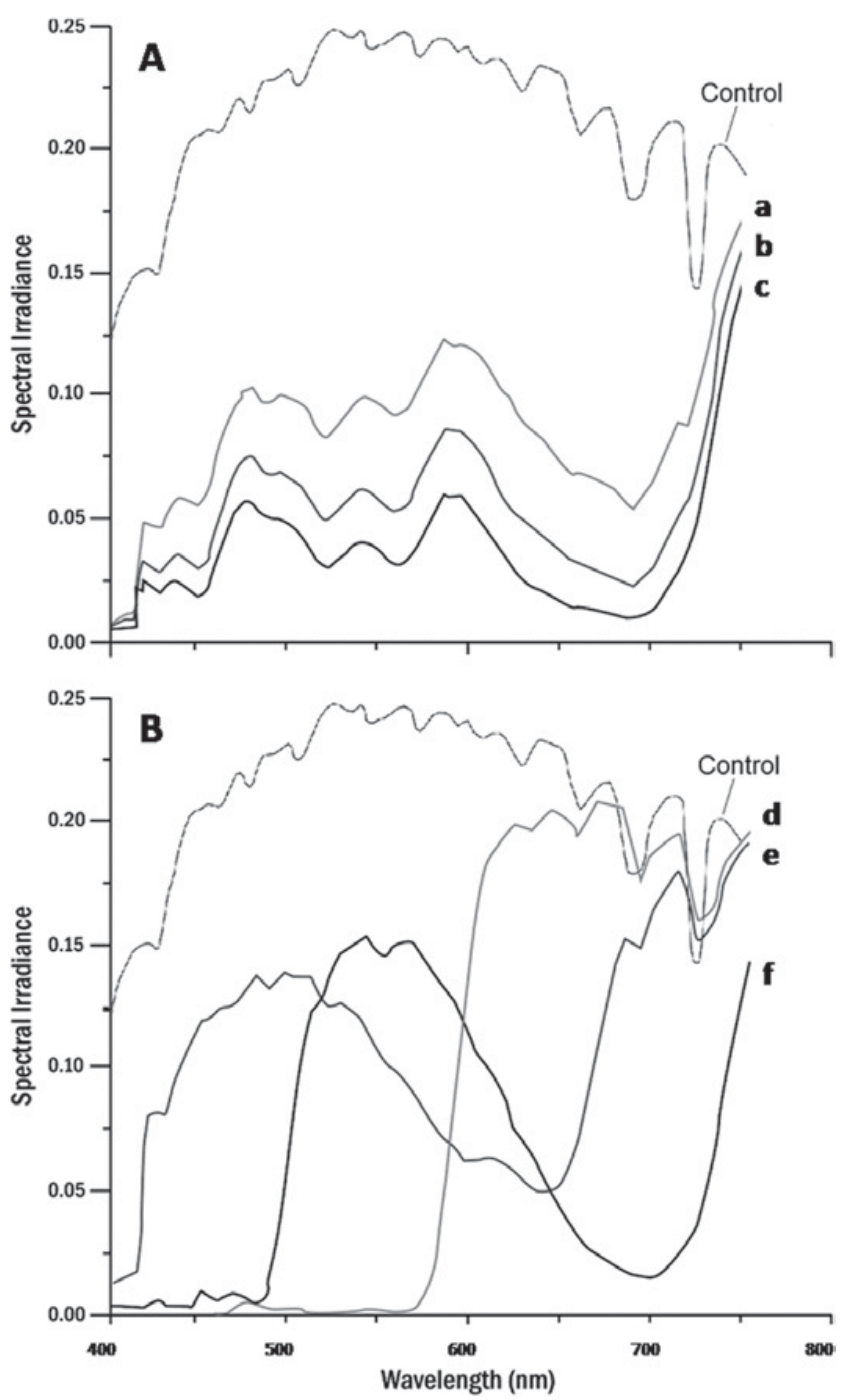

Fig. 1. The spectral composition curves of the quantitative and qualitative treatments developed in the experiment. Quantitative treatments (A): a, $50 \%$ of attenuation; b, $70 \%$ of attenuation; c, $90 \%$ of attenuation. Qualitative treatments (B): d, red light; e, blue light; f, green light.

different $(F=1.88 ; P=0.21)$, while in the quantitative treatments, the irradiance values were all statistically different $(F=335.9 ; P<0.001)$.

The randomized complete block design was used to control for environmental heterogeneity (Sokal and Rohlf, 2000; Goteli and Ellison, 2004). This is a type of two-way analysis of variance (ANOVA; usually without replication) and has been used in other aquatic ecological studies (e.g., Flecker and Townsend, 1994; Flecker et al., 2002; Usio and Townsend, 2004; Bechara et al., 2007; Landeiro et al., 2008), including for stream algal communities (DeNicola and Hoagland, 1996). Since the variation between blocks can be adjusted for differences in the treatments under comparison, this experimental design is considered efficient for highly variable environments (Goteli and Ellison, 2004).

A set of seven samplers, one for each treatment, was attached to a concrete plate of $1 \mathrm{~m}^{2}(\sim 20 \mathrm{~kg})$ and installed 
Table 1. Values of physical and chemical water parameters in studied streams during the experimental period.

\begin{tabular}{|c|c|c|c|c|c|c|c|c|c|}
\hline & Streams & $\begin{array}{c}\text { Temperature } \\
\left({ }^{\circ} \mathrm{C}\right)\end{array}$ & $\mathrm{pH}$ & $\begin{array}{c}\text { Dissolved } \\
\text { oxygen } \\
\left(\mathrm{mg.L}^{-1}\right) \\
\end{array}$ & $\begin{array}{l}\text { Conductance } \\
\left(\mu \mathrm{S} . \mathrm{cm}^{-1}\right)\end{array}$ & $\begin{array}{l}\text { Turbidity } \\
\text { (NTU) }\end{array}$ & $\begin{array}{c}\text { Current } \\
\text { speed } \\
\left(\mathrm{cm} \cdot \mathrm{s}^{-1}\right) \\
\end{array}$ & $\begin{array}{c}\text { Total } \\
\text { nitrogen } \\
\left(\mathrm{mg.} \mathrm{L}^{-1}\right)\end{array}$ & $\begin{array}{c}\text { Total } \\
\text { phosphorus } \\
\left(\mathrm{mg} . \mathrm{L}^{-1}\right)\end{array}$ \\
\hline \multirow{5}{*}{$\overline{\text { Day } 15}$} & $\bar{A}$ & 16 & 7.61 & 9.02 & 55 & 23 & 35.5 & 0.47 & 0.16 \\
\hline & B & 16.8 & 7.57 & 8 & 39 & 20 & 30.9 & 0.39 & 0.12 \\
\hline & $\mathrm{C}$ & 16.1 & 7.14 & 8.77 & 56 & 18 & 32.5 & 0.45 & 0.15 \\
\hline & $\mathrm{D}$ & 16.3 & 7.67 & 8.04 & 45 & 27 & 22.3 & 0.41 & 0.14 \\
\hline & Mean & $16.2 \pm 0.3$ & $7.4 \pm 0.2$ & $8.4 \pm 0.5$ & $48.7 \pm 8.1$ & $22.0 \pm 3.9$ & $30.3 \pm 5.6$ & $0.43 \pm 0.03$ & $0.14 \pm 0.016$ \\
\hline \multirow[t]{5}{*}{ Day 39} & A & 12.8 & 7.35 & 9.96 & 37 & 11 & 34.4 & 0.35 & 0.11 \\
\hline & B & 13 & 7.18 & 9.32 & 41 & 16 & 22.5 & 0.42 & 0.13 \\
\hline & $\mathrm{C}$ & 12 & 6.71 & 10.05 & 31 & 15 & 29.7 & 0.37 & 0.10 \\
\hline & $\mathrm{D}$ & 11.5 & 6.57 & 9.88 & 37 & 20 & 25.1 & 0.40 & 0.12 \\
\hline & Mean & $12.3 \pm 0.7$ & $6.9 \pm 0.3$ & $9.8 \pm 0.3$ & $36.5 \pm 4.1$ & $15.5 \pm 3.7$ & $27.9 \pm 5.2$ & $0.38 \pm 0.03$ & $0.11 \pm 0.01$ \\
\hline \multirow[t]{5}{*}{ Day 70} & A & 12.8 & 6.92 & 10 & 34 & 42 & 72.9 & 0.45 & 0.13 \\
\hline & B & 13.1 & 7.03 & 9.89 & 30 & 68 & 80.2 & 0.52 & 0.18 \\
\hline & $\mathrm{C}$ & 11.8 & 6.6 & 10.23 & 31 & 58 & 74.6 & 0.48 & 0.11 \\
\hline & $\mathrm{D}$ & 11.5 & 6.67 & 9.53 & 37 & 44 & 63.2 & 0.43 & 0.12 \\
\hline & Mean & $12.3 \pm 0.7$ & $6.8 \pm 0.2$ & $9.9 \pm 0.3$ & $33 \pm 3.1$ & $53.0 \pm 12.2$ & $72.7 \pm 7.0$ & $0.47 \pm 0.04$ & $0.13 \pm 0.013$ \\
\hline
\end{tabular}

in riffle areas of each stream, totaling four replicated blocks. The concrete plates were used to avoid samplers drifting and guarantee submersion. Within each block, treatments were randomly placed. The experiment was entirely conducted during the fall-winter seasons, the most favorable time for the development of the macroalgal communities in the study region (Branco et al., 2009). The blocks were installed in April 2009 and remained in the streams for 70 days. This was sufficient for effective colonization and not long enough to encounter marked seasonal variations in the environment. The duration of the experiment was similar to that of a previous study (Branco et al., 2010). Samplers were evaluated three times during the experimental period: (i) early stage of macroalgal colonization (day 15); (ii) intermediate stage (day 39); and (iii) late stage (day 70).

Measurements were made on each sampling occasion of water temperature, $\mathrm{pH}$, dissolved oxygen, turbidity and conductivity using the water analyzer Horiba U-10. Current velocity was measured inside the tubes using a Swoffer 3000 flowmeter (Table 1). Nutrients concentrations were high throughout the study period (Table 1).

Digital images of the artificial substrates were also collected on each visit for qualitative and quantitative data collection. For the quantitative analyses, the colonized glass plaques were individually removed from their samplers and immediately photographed with a Canon digital camera (Model Powershot A630, 8.0 Megapixels). All photographs were taken with the camera $15 \mathrm{~cm}$ above the colonized glass plaques. The images of the colonized plaques were then analyzed using software (AutoCad version 2008) with the objective of quantifying the community and each morphological type (=macroalgal taxa). Microscopic algae associated with the macroalgae were not considered in these analyses. For each photograph, the substratum area covered by a particular macroalgal morphological type was marked using a digitalizer board with the help of the AutoCad selection tool. Following this, we used a specific software function (Area) to sum all marked areas covered by an individual macroalgal morphological type to measure its percentage cover. This was repeated for all macroalgal morphological types on colonized substrates in each photo. To measure the percentage cover of the macroalgal community as a whole, we summed the percentage cover of all individual morphological types in each photo. We used the AutoCad scale function to standardize the scale for all images. This technique was adapted from other studies (e.g., Englund et al., 2000; Rico-Garcia et al., 2009) and allowed us to increase the precision of the measure of abundance (as percentage area) compared with visual analysis (e.g., Sheath and Cole, 1992; Necchi et al., 2000).

Each morphological type was examined in the laboratory with a microscope (Leica DM 1000) equipped for capturing and analyzing images (Leica DFC 280). After identification, species were associated with its correspondent morphological type observed in the colonized plaques.

Macroalgal abundance during the period was arcsinesquare root transformed to normalize the data. Differences between treatments for percent cover of the individual species and the macroalgal communities were tested by a randomized block ANOVA, with the four sites as blocks (DeNicola and Hoagland, 1996). This analysis was conducted for each day on which the samplers were checked (days 15, 39 and 70). All analyses were conducted using software Statistica version 7.0.

\section{Results}

Four species of macroalgae were identified: Tetraspora lubrica (Roth) C. Agardh (Chlorophyta); Draparnaldia mutabilis (Roth) Bory (Chlorophyta); Batrachospermum puiggarianum Grunow (Rhodophyta); and Microcrocis sp. (Cyanobacteria). Batrachospermum puiggarianum was 



Fig. 2. The percent cover values for the irradiance treatments to the entire community of macroalgae, Microcrocis sp., Tetraspora lubrica and Batrachospermum puiggarianum. The different letters indicate statistical differences. Error bars represent standard deviation. $N=4$.

recorded in only one stream, while $D$. mutabilis was found on just one sampling occasion.

The mean values of percentage cover for the communities of macroalgae decreased with the attenuation of light (Fig. 2), and the ANOVA revealed significant differences between treatments on days 15 and 39 $(F=10.18, P<0.01 ; F=6.39, P<0.05$, respectively). In both days, IR 90 differed from CT $(P<0.01$ and $P<0.05$, respectively for ES and IS) and IR50 $(P<0.05$, in both stages). On day 70, ANOVA showed no significant differences.

The growth pattern of the macroalgal community was strongly influenced by the response of $T$. lubrica, which was dominant throughout the experimental period (Fig. 2). The ANOVA for this species showed significant differences on days 15 and $39(F=5.60, P<0.05 ; F=8.46$, 

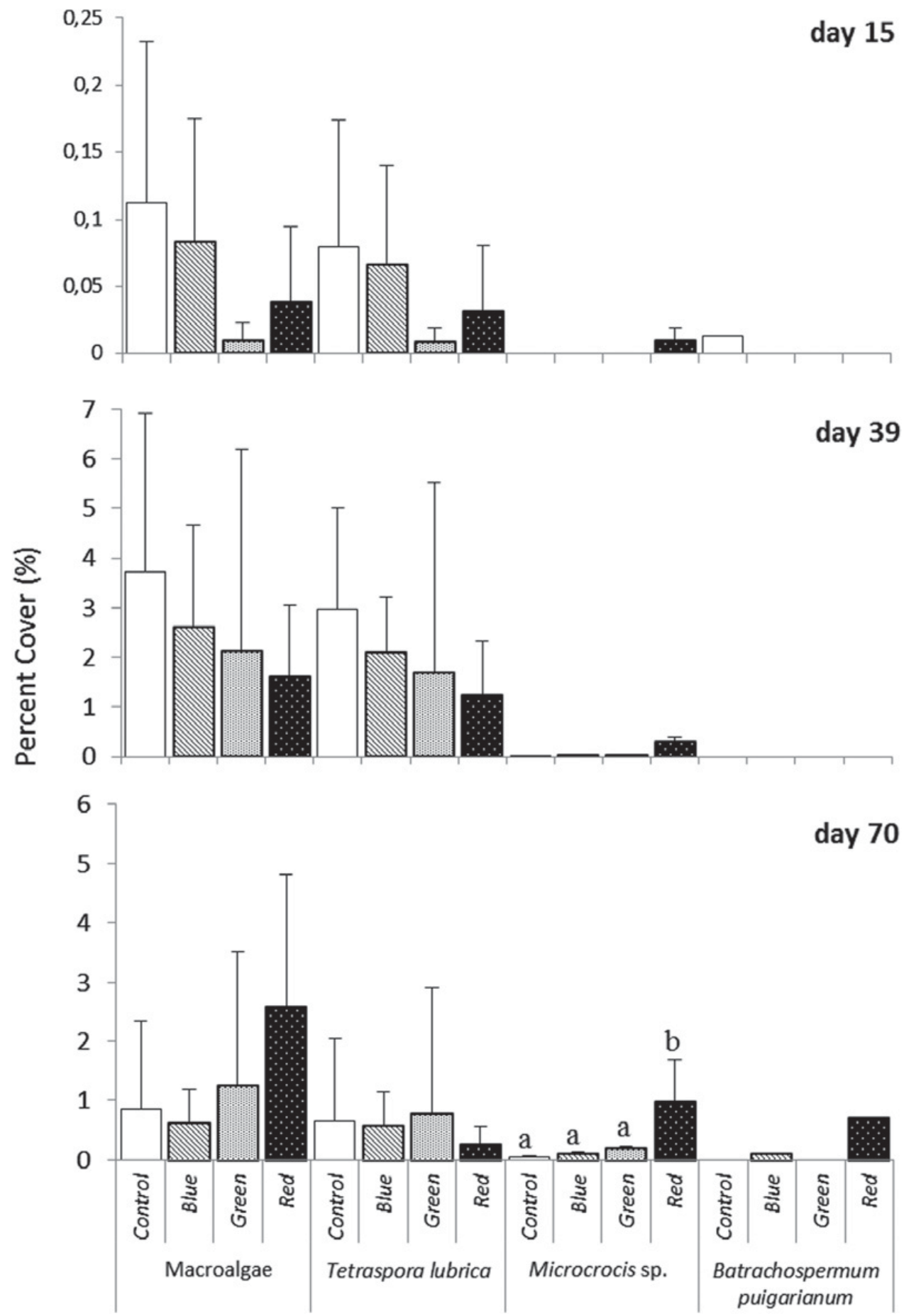

Fig. 3. The percent cover values for the spectral composition treatments to the entire community of macroalgae, Microcrocis sp., Tetraspora lubrica and Batrachospermum puiggarianum. The different letters indicate statistical differences. Error bars represent standard deviation. $N=4$.

$P<0.05$, respectively), but no significant differences on day 70 . However, the differences were only found between IR90 and CT $(P<0.05$, in both stages $)$. In contrast, Microcrocis sp. had low values of percentage cover, which were similar among treatments (Fig. 2) and the ANOVA revealed no significant differences at any stage. Batrachospermum puiggarianum showed low percentage cover with the highest value in the FS stage in
IR50. This taxon occurred in only one stream and the ANOVA test was not applied.

Considering the spectral composition treatments, mean values of macroalgal communities were higher in CT followed by BL on days 15 and 39, while on day 70, the RD was higher than the others (Fig. 3). The response of T. lubrica was very similar again, except on day 70, when the higher value of percentage cover was observed in GR. 
ANOVA revealed no significant differences in any phase for macroalgal communities or T. lubrica itself (Fig. 3).

On the other hand, Microcrocis sp. presented higher percentage cover in RD than in the other treatments, including CT (Fig. 3). This response was observed in all stages and the ANOVA revealed significant differences on day $70(F=7.27, P=0.009)$ (Fig. 3). Batrachospermum puiggarianum also showed higher cover in red light.

\section{Discussion}

We found that percent cover of macroalgae significantly differed among light treatments, suggesting that the effects of light were an important factor in the establishment of stream macroalgae. The IR90 had an almost complete absence of macroalgae, versus treatments with higher irradiance, in which the algal communities displayed evident growth, suggesting that the effects of irradiance play an important role in macroalgal establishment. Considering that macroalgae are important primary producers within stream food webs (Stevenson et al., 1996; Lowe and Laliberte, 2006), this result suggests that changes in irradiance level could affect the stream communities as a whole. Others (e.g., DeNicola and Hoagland, 1996; Mosisch et al., 2001) have found similar controlling influences of shading.

Each species found in this study showed a particular response for quantitative treatments. Microcrocis sp. did not reveal any preference for light conditions, suggesting a weak influence of this variable on the development of this taxon. This result could help to explain the presence, sometimes predominant, of this algal group in lotic environments with different degrees of shading (Necchi et al., 2008) and can be related to the indifferent response of their photosynthetic apparatus to different light levels (Necchi, 2004). Tetraspora lubrica, however, presented a clear development of percent cover under higher light intensity, which is typical for Chlorophyta (Richardson et al., 1983; Necchi, 2004). The pigment composition of Chlorophyta limits them to predominately high irradiance sections of streams (DeNicola and Hoagland, 1992). Batrachospermum puiggarianum presented low percentage cover for $\mathrm{CT}$ in all stages, making it evident that this species possesses a tendency to inhabit environments with moderate to low light intensities (Necchi and Zucchi, 2001), what is frequently reported for Rhodophyta (Hynes, 1970; Necchi, 2004). The light response of B. puiggarianum is supported by the fact that the threshold of net photosynthesis is reached under low irradiances for red algae, which can impose serious constraints to tolerate higher irradiances, such as photodamage to the photosynthetic apparatus (Necchi and Zucchi, 2001).

The spectral composition treatments showed that the community of macroalgae presented higher percent cover in the RD on day 70 , mainly as a function of the higher relative abundance of Microcrocis sp. and B. puiggarianum. However, ANOVA showed no significant differences, suggesting that the effects of spectral composition of light on macroalgal community as a whole were minor compared with the effects of light intensity. Other investigators have also concluded that variation in light intensity is much more important than spectral quality for stream periphytic communities (DeNicola and Hoagland, 1996) and for algal communities in other aquatic habitats (Falkowski and LaRoche, 1991).

However, some species-level spectral differences were apparent. Microcrocis sp. had a clear preference for red light. This response results from the presence of phycobiliproteins, which are typical for Cyanobacteria (Marsac, 1977). The film of red light transmitted longer wavelengths (between 600 and $700 \mathrm{~nm}$; Fig. 1); which is the region where high rates of the synthesis of phycocyanin and allophycocyanin occur in some species of Cyanobacteria (Haury and Bogorad, 1977; Vogelman and Scheibe, 1978). Thus, the higher percentage cover and the increasing percent cover over time of Microcrocis sp. under red light suggests that this species exhibited chromatic adaptation that allowed a higher efficiency in this wavelength, as previously reported for other Cyanobacteria. Batrachospermum puiggarianum had a similar preference to red light. Rhodophyta produces a pigment complex similar to that found in Cyanobacteria (Cole and Sheath, 1990; Lee, 2008). This positive effect of red light in Microcrocis sp. and B. puiggarianum can additionally have influenced the responses of these algae in quantitative treatments, which showed a reduction in this part of the spectrum. Differently, T. lubrica had higher percentage cover in the CT and in the treatments with shorter wavelengths and higher energy (BL and GR). This response may be related to a group of accessory pigments, particularly $\beta$-carotene, which is characteristic of Chlorophyta (Demming-Adams and Adams, 1992).

Engleman (1882, in Saffo 1987) was the first to suggest, for seaweeds, that the taxonomic composition of algal assemblages in different spectral regimes can be influenced by differences in photosynthetic pigments among algal divisions, but debate continues on this subject (Kirk, 1983; Saffo, 1987; DeNicola and Hoagland, 1996). In this study, macroalgae species showed different responses in both quantitative and qualitative treatments, suggesting a close relationship between algal groups that these species represent particularities of light (irradiance or spectral composition) available in the environment.

Recognition of variation in irradiance and spectral composition may contribute to understanding the distribution of lotic macroalgal communities in natural habitats. The relation between the typical photosynthetic pigment of each algal division and characteristics of light in a habitat can help to explain some of the variation in the structure of stream macroalgal communities. Further physiological studies evaluating the composition and synthesis of photosynthetic pigments among algal divisions, subjected to different light conditions, would help to gain a better understanding of the photosynthetic performance of stream macroalgae and how it could affect the ecological distribution of these organisms. 
Acknowledgements. We thank Brian Allan Whitton for his great scientific review of our manuscript and Pitágoras C. Bispo for help with the statistical analysis. This research was financially supported by Fundação de Amparo a Pesquisa do Estado de São Paulo - FAPESP (Proc. 07/52608-1), by Conselho Nacional de Desenvolvimento Científico e Tecnológico - CNPq (Proc. 302354/2008-5) and by Coordenação de Aperfeiçoamento de Pessoal de Nível Superior - CAPES.

\section{References}

Antoine S.E. and Benson-Evans K., 1983a. The effect of light intensity and quality on the growth of benthic algae. I. Phytopigment variations. Arch. Hydrobiol., 98, 299-306.

Antoine S.E. and Benson-Evans K., 1983b. The effect of light intensity and quality on the growth of benthic algae. II. Population dynamics. Arch. Hydrobiol., 99, 118-128.

Bechara J.A., Planas D. and Paquet S., 2007. Indirect effects of brook trout (Salvelinus fontinalis) on the structure of epilithic algal communities in an oligotrophic boreal forest stream. Fundam. Appl. Limnol., 169, 89-99.

Branco C.C.Z. and Necchi O. Jr, 1996. Survey of stream macroalgae of eastern Atlantic Rainforest of São Paulo State, southeastern Brazil. Arch. Hydrobiol., 80, 35-57.

Branco C.C.Z., Krupek R.A. and Peres C.K., 2009. Distribution of stream macroalgal communities from the mid-western region of Paraná State: importance of local scale variation. Braz. Arch. Biol. Technol., 52, 379-386.

Branco C.C.Z., Necchi O. Jr and Peres K.P., 2010. Effects of artificial substratum types and exposure time on macroalgal colonization in a tropical stream. Fundam. Appl. Limnol., $178,17-27$.

Cole K.M. and Sheath R.G., 1990. Biology of the Red Algae, Cambridge University Press, New York, 517 p.

Demming-Adams B. and Adams W.W. III, 1992. Photoprotection and other responses of plants to high light stress. Annu. Rev. Plant Physiol. Plant Mol. Biol., 43, 599-626.

DeNicola D.M. and Hoagland K.D., 1992. Influences of canopy cover on spectral irradiance and periphyton assemblages in a prairie stream. J. North. Am. Benthol. Soc., 11, 391-404.

DeNicola D.M. and Hoagland K.D., 1996. Effects of solar spectral irradiance (Visible to UV) on a Prairie stream epilithic community. J. North. Am. Benthol. Soc., 15, 155-169.

Englund S.R., O'Brien J.J. and Clark D.B., 2000. Evaluation of digital and film hemispherical photography and spherical densiometry for measuring forest light environments. Can.J. Forest Res., 30, 1999-2005.

Falkowski P.G. and LaRoche J., 1991. Acclimation to spectral irradiance in algae. J. Phycol., 27, 8-14.

Flecker A.S. and Townsend C.R., 1994. Community-wide consequences of trout introduction in New Zealand streams. Ecol. Appl., 4, 798-807.

Flecker A.S., Taylor B.W., Bernhardt E.S., Hood J.M., Cornwell W.K., Cassatt S.R., Vanni M.J. and Altman N.S., 2002. Interactions between herbivorous fishes and limiting nutrients in a tropical stream ecosystem. Ecology, 83, 1831-1844.

Goteli N.J. and Ellison A.M., 2004. A primer of Ecological Statistics, Sinauer Associates Publishers, Massachusetts, $510 \mathrm{p}$.
Haury J.F. and Bogorad L., 1977. Action spectra for phycobiliprotein synthesis in a chromatically adapting cyanophyte. Plant Physiol., 60, 835-839.

Hill W.R., 1996. Effects of light. In: Stevenson R.J., Bothwell M.L. and Lowe R.L. (eds.), Algal Ecology: Freshwater Benthic Ecosystems, Academic Press, San Diego, 121-148.

Hill W.R., Mulholland P.J. and Marzolf E.R., 2001. Stream ecosystem responses to forest leaf emergence in spring. Ecology, 82, 2306-2319.

Hill W.R., Ryon M.G. and Schilling E.M., 1995. Light limitation in a stream ecosystem: responses by primary producers and consumers. Ecology, 76, 1297-1309.

Hynes H.B.N., 1970. The Ecology of Running Waters, University of Toronto Press, Toronto, $555 \mathrm{p}$.

King D.K. and Cummins K.W., 1989. Autotrophic-heterotrophic community metabolism relationship of the woodland stream. J. Freshwater Ecol., 5, 205-218.

Kirk J.T.O. 1983. Light and Photosynthesis in Aquatic Environments, Cambridge University Press, Cambridge, UK.

Landeiro V.L., Hamada N. and Melo A.D., 2008. Responses of aquatic invertebrate assemblages and leaf breakdown to macroconsumer exclusion in Amazonian "terra firme" streams. Fundam. Appl. Limnol., 172, 49-58.

Lee R.E., 2008. Phycology (4th edn,), Cambridge University Press, New York, 547 p.

Lowe, R.L. and Laliberte G.D., 2006. Benthic stream algae: distribution and structure. In: Hauer F.R. and Lamberti G.A. (eds.), Methods in Stream Ecology (2nd edn,), Academic Press, San Diego, California, 327-356.

Marsac N.T., 1977. Ocurrence and nature of chromatic adaptation in Cyanobacteria. J. Bacteriol., 130, 82-91.

Mosisch T.D., Bunn S.E. and Davies P.M. 2001. The relative importance of shading and nutrients on algal production in subtropical streams. Freshwater Biol., 46, 1269-1278.

Necchi O. Jr, 2004. Light-related photosynthetic characteristics of lotic macroalgae. Hydrobiologia, 525, 139-155.

Necchi O. Jr, Branco C.C.Z. and Branco L.H.Z., 2000. Distribution of stream macroalgae in São Paulo state, Southeastern Brazil. Algol. Stud., 97, 43-57.

Necchi O. Jr, Branco L.H.Z. and Spezamiglio D.N., 2008. Distribuição ecológica das comunidades de macroalgas de ambientes lóticos do Parque Nacional de Itatiaia (RJ, MG), Brasil. Rev. Bras. Bot., 31, 135-145.

Necchi O. Jr and Zucchi M.R., 2001. Photosynthetic performance of freshwater Rhodophyta in response to temperature, irradiance, $\mathrm{pH}$ and diurnal rhythm. Phycol. Res., 49, 305-318.

Richardson K., Beardall J. and Raven J.A., 1983. Adaptation of unicellular algae to irradiance: an analysis of strategies. New Phytol., 93, 157-191.

Rico-Garcia E., Hernández-Hernández F., Soto-Zarazúa G.M. and Herrera-Ruiz G., 2009. Two new Methods for the Estimation of Leaf Area using Digital Photography. Int. J. Agric. Biol., 11, 397-400.

Rier S.T., Stevenson J. and Laliberte G.D., 2006. Photoacclimation response of benthic stream algae across experimentally manipulated light gradients: a comparison of growth rates and net primary productivity. J. Phycol., 42, 560-567.

Roberts S., Sabater S. and Beardall J., 2004. Benthic microalgal colonization in stream of differing riparian cover and light availability. J. Phycol., 40, 1004-1021. 
Saffo M.B. 1987. New light on seaweeds. BioScience, 37, 654 664.

Sheath R.G. and Burkholder J.M., 1985. Characteristics of softwater streams in Rhode Island II. Composition and seasonal dynamics of macroalgal communities. Hidrobiologia, 28, 109-118.

Sheath R.G. and Cole K.M., 1992. Biogography of stream magroalgal in North America. J. Phycol., 28, 448460 .

Shortreed K.S. and Stockner J.G., 1983. Periphyton biomass and species composition in a coastal rainforest stream in British Columbia: effects of environmental changes caused by logging. Can. J. Fish. Aquat. Sci., 40, 18871895.
Simão E., Nakamura A.T. and Takaki M., 2008. Use of Insulfim ${ }^{\mathbb{B}}$ like plastic filter to simulate canopy filtered light for germination tests. Naturalia, 31, 28-33.

Sokal R.R. and Rohlf F.J., 2000. Biometry, W. H. Freeman and Company, San Francisco, 887 p.

Stevenson R.J., Bothwell M.L. and Lowe R.L., 1996. Algal ecology - Freshwater Benthic Ecosystems, Academic Press, San Diego, 753 p.

Usio N. and Townsend C., 2004. Roles of crayfish: consequences of predation and bioturbation for stream invertebrates. Ecology, 85, 807-822.

Vogelman T.C. and Scheibe J., 1978. Action spectrum for chromatic adaptation in the blue-green alga Fremyella diplosiphon. Planta, 143, 233-239. 